\title{
The Anomaly of Bankruptcy in the Indonesian Mining Law
}

\author{
Al Araf \\ The Indonesian Human Right Monitor \\ Jakarta, Indonesia \\ aalski1@yahoo.com
}

\author{
Hendra Kurnia Putra \\ Ministry of Law and Human Right \\ Jakarta, Indonesia \\ hendra_kurnia_putra@yahoo.com
}

\author{
Awan Pury adi \\ The Jakarta Legal Strategic Law Firm \\ Jakarta, Indonesia \\ awanpuryadijkt@gmail.com
}

\begin{abstract}
Indonesian mining law has decided to adopt bankruptcy as a tool of power to control mining business in Indonesia. Under article 119 Act number 4 year 2009 states that government has the authority to withdraw mining licenses in the event of bankruptcy. In this law states in this cases is government exercises its power by utilizing bankruptcy system. But bankruptcy is not regulations that stand alone; it is a system that has been built through principles of law and constitutional process. Furthermore, bankruptcy system has clearly states that in order to protect the right of creditors and debtor (both parties are identified as citizens) the existence of principle of continuation of business is clearly taken in the article 104 Act number 37 year 2004. The law ensures that the debtor that has been declared as bankrupt has the right under the approval of the board of creditor to be operated in order to open the possibility of acquiring payment through business operation and also to be able to pay debtor obligation to society and to the state. The contradiction of Indonesian mining law and Indonesian Bankruptcy law is clearly seen. This paper is aimed to address that the principles of law and constitutional rights has heavily chosen its side to bankruptcy law other than mining law.
\end{abstract}

Keywords—mining law, bankruptcy law, constitution.

\section{INTRODUCTION}

Indonesian mining law is regulated under Act number 4 years 2009. Post to its installment in the Indonesian legal system, the law was heavily criticized by mining business practitioners mostly for its nature which requires mining company to own complete processing unit so that all mining products must be exported as processed products. Attempts to change the law have failed in the face of constitutional court decision which strongly ruled in favor of the mining law. But aside from this is sue, Indonesia mining law actually regulates another issue that could hurt not only mining business industry but also citizen's fundamental rights which is guaranteed in the constitution. This matter is related to bankruptcy.

Bankruptcy law in Indonesia is regulated under Act number 37 years 2004. The law comprehensively covers the principal of bankruptcy which ensures the protection of citizen as both creditors and debtors [1]. In the bankruptcy system creditor and debtor are well protected because creditor has access and choice to utilize the best way to acquire creditor's right of payment from debtor.

Creditor on one hand is granted an access to get the payment from all debtors' property, on the other hand if the debtor is a company; creditor also holds the right to run the company until this activity satisfied the amount of debtor's debt (The principal of Paritas Criditorium and the principal of Pari Passu Prorata Parte)[1]. This well-tailored regulation guarantees the fulfillment of the principal of equality before the law to all citizen and the fundamental economic and social rights which are the heart of constitution. But this harmony of legal system is deserted by the Indonesian mining law which is regulated under Act number 4 years 2009. In article of 119 of this mining law states that government has the authority to withdraw all mining company's licenses in the event of bankruptcy. This law eliminates both creditor and debtor legal right that is protected under bankruptcy law. Without any licenses mining company is not able to be operated and this situation undermines the right of creditor and debtor to get and to do payment by agreeing to the company's operation regulated underbankruptcy law.

The bankruptcy law has set the legal certainty in the bankruptcy system in Indonesia, under article 104 verse 1 Act number 37 year 2004 regulates that under the board of temporary creditor, and curator may continue the operation of debtor's business after the company is declared as bankrupt. This part of bankruptcy regulation gives option for creditor to get the payment from the debtor business. In this way creditor interest is protected through payment from the debtor in various possible way effectively, transparently and fairly, moreover this regulation ensures the implementation of the principles of business continuation principles [2]. The principles of bankruptcy is well enacted in bankruptcy law in Indonesia the implementation of this principles in bankruptcy law has shown that Indonesian bankruptcy system is created under the guidance of solid legal frame work. The appearance of article 119 of the Act number 4 year 2009 especially the part where government is given the authority to withdraw mining licenses in the event of bankruptcy rise a question about how this mining law related to bankruptcy was created and how it undermines the bankruptcy system.

\section{THE PRINCIPLES OF BANKRUPTCY AND INDONESIAN MINING LAW}

The principle of law lies at the heart of regulation and act broad foundation of regulation, it means that regulation can be simplicity explained by principle of law[3]. The principle of law is able to give unending birth of legal regulation[4]. Through this universal understanding we understand that the principle of law has the higher position and more important than legal regulation. 
The first important principle in the law of bankruptcy is " Paritas Creditorium" which can be broadly explained as the equality position of creditors, If a debtor has no ability to pay back the debt, all debtors' property becomes the object of the payment to creditors [5]. The second principle of bankruptcy law is Pari Passu Prorata Parte. This principle of law explains that all debtors' property is collective collateral to creditors therefore it must be proportionally distributed among creditors except legally there is a creditor that must be prioritized by law[6]. Bankruptcy principle also completed by other principles that are acting as foundation of bankruptcy law. One principle in particular has direct connection with Indonesian mining law.

The principle of business continuation is the basic of the bankruptcy law in Act number 37 years 2004, this principle enables a debtor company that has high economic value can still be operated in the event of bankruptcy.

\section{Article 104 Act number 37 years 2004:}

"Under the permission of temporary Board of creditor, curator is able to continue debtor business under bankruptcy systemeven this bankruptcy decision is being appealed."

This law has strongly adopted the principle of business continuation in the bankruptcy system. In the event of rescheduling the debt, debtor may continue to operate the business in order to be able for the debtor acquire reasonable time and use maximum potential of the business to pay the debt[7].

The application of this principle potentially adding more revenue to the debtor business which could directly contribute to the payment of the debt, payment of about expenses, government taxes and corporate social responsibility. This situation brings conducive business environment to the debtor to pay all the obligation and maximize business potential[7].

\section{CONSTITUTIONAL LAW AND INDONESIAN MINING LAW}

The birth of a regulation can never be seen as individual birth of law; it is connected with state and its constitution. Constitution explains and represents the very reas on and very rational of collective human kind.

\section{A. State and Constitution}

Plato is the very first person to put forward the idea of rechtsstaat, and then this thought was reaffirmed by Aristoteles [8]. According to Aristoteles, the one who govem in a nation is not human but righteous mind and decency that determined the good or bad of rule of law. A good nation is commanded by constitutions and sovereignty of the law. He stated that:

"Constitutional rule in a state is closely connected, also with the question whether is better to be ruled by the best men or the best law, since a govemment in accordance with law, accordingly the supremacy of law is accepted by Aristoteles as mark of good state and not merely as an unfortunate necessity."

Aristoteles also suggested three elements from a constitutional government. First, the government is held for public interest. Second, the government is held according to the law that are based on common provision and not the law that were made arbitrarily, ignoring convention and constitutions. The third, constitutional government is carried at the will of the people[9]. These thought from Aristoteles, were recognized to be the ideals of the rechtsstaat that are known one day. In fact, those three elements could be found and practiced in every country who claimed them to be the rechtsstaat.

The concept of rechtsstaat in European continent was based on individualistic liberal philosophy. The individualistic traits are very prominent in the thought of rechtsstaat based on European concept. Meanwhile, the concept of rechtsstaat according to Philipus. M Hadjon, was borne from a fight against absolutism and the fore is revolutionary[10]. The characteristic of rechtsstaat are :

There are constitution that contained written conditions about the relationship between the ruler and the people.

They are the division of state power

Recognized and protected the rights of the people's freedom

Fro $m$ those characteristic, the central idea of rechtsstaat is the recognition and protection of humans rights which rest in liberty principle and equality before the law. The existence of constitutions, theoretically, gave constitutional guarantee on those principles. The division of power intended to prevent power buildup in one hand from happening. Excessive strength owned by one ruler tends to curb freedom and equality which supposed to be the main characteristic of rechts staat.

The characteristic of democratic rechtsstaat are committed to the appearance of the law as the holder of controls in democratic governance. The democratic governance can be measured based on how serious the country respect human rights. Human rights will be protected is the country put forward equality before the law principle[9].

\section{B. The Equality Before The Law}

The idea of rechtsstaat is to put law principles as the highest power therefore law would be the highest ruler and not man, just like what Albert Venn Dicey stated "the rule of law and not of man". The term Rule of Law, according to Friedman could not be interpreted formally and narrowly only limited to the enforcement of the legislation. It has to be interpreted materially to include a definition of righteousness that is more essential rather than just simply the enforcement of the law.

In the International Convention of the Civil and Political Rights, in the article 14 (1) ICCPR it is mentioned that, "all pers on shall be equal before the courts and tribunals. in the determination of any criminal charge against him, or of his rights and obligation in any suit at law, everyone shall be entitled to a fair and public hearing by a competent, independent and impartial tribunal established by law".

Furthermore, the concept of the rechtsstaat have other important characteristic which was put forward by AV Dicey, they are the presence of Supremacy Of Law, Equality before the law and Due Process Of Law. in the context of rechtsstaat, Jimly Asshiddiqie argue that there are at least 12 basic principles of the rechtsstaat that are applicable in the present day. Those twelve principles are the supremation of law, equality before the law, due process of law, limitation of 
power, independent executive organ, impartial and independent judiciary, administrative court, constitutional court, human rights protection, democratische rechsstaat, welfare rechtsstaat, transparency and social control.

One of the Rechtsstaat element which is equality before the law is also recognized by the 1945 constitution Article 27 paragraph (1) which said "every citizens are equal before the law and government and shall uphold such law and government with no exception" Furthermore, in the article of 28D paragraph (1) the 1945 constitution also explained: "Everyone is entitled to the recognition, guarantee, protection and legal certainty of justice and equal treatment before the law". Equality before the law, besides being the important element of rechtsstaat, it is also an embodiment of the basic principles of the human rights which is based on the idea that everybody is born free and equal, as expressed by Thomas Jefferson, "that all men are created equal, in terms of their basic societal rights". Equality before the law also has two important definition related to judicial process, first refers to gender, race, status, or basically saying that everyone brought before the judiciary have the right to obtain equality either in the application of the law or the proceedings of legal proceedings, and the second is that there should be equal access for everyone in court.

\section{INDONESIA MINING LAW UNDERMINES PRINCIPLES OF LAW AND CONSTITUTIONAL RIGHTS}

The bankruptcy system in Indonesia is built and created to ensure constitutional rights of citizen (debtors and creditors) are guaranteed. In the Indonesia mining law bankruptcy is chosen as a tool of controlling the operation of a company. Under article 119 Act number 4 years 2009 (Mining Law) government is given the authority to withdraw all mining company licenses. The absent of mining licenses, means that the mining company could not be operated. Mining licenses in Indonesia is varied from district government, provincial government up until central government and consist of much kind of licenses which is connected to each other. This complex requirement is usually fulfilled by mining by years of licenses application and process. Moreover, mining license to itself brings great value to mining company and determines the value of the company. In this case mining license is vital to mining company.

It is understandable that the vital position of mining licenses motivates the government to use it as a tool of control and power for the government. In this regard government must be able to utilize this power in the correct manner so the affectivity of this tool can be exercised. The adoption of utilizing this tool can clearly be seen in the Act number 4 year's 2009 article 119.

The article of 119 Act number 4 years 2009 also utilize bankruptcy as a tool of power. I9n the event of bankruptcy government is given the authority to withdraw mining company licenses. The utilization of bankruptcy in this article can also be transparently seen that it is contradicted with the principle of business continuation that has been elaborately tailored in Indonesia bankruptcy law. The Indonesian mining law undermines the principle of bankruptcy law and undermine the general principle of law in this regard is the principle of conflict of law especially the principle of lex specialis derogat lex generalis.
The utilization of bankruptcy to withdraw mining company licenses also directly eliminates a citizen right that has been carefully protected under the constitution. Creditors that originally is given the right to access debtor property through bankruptcy system has been circumcised its rights by mining law regulation. The circumzation is exercised through the withdrawing of all mining licenses in the event of bankruptcy. Creditor does not have access anymore to acquire payment from debtor through operating the business meanwhile debtor's rights has also erase by mining law. Indonesia as a state based on law has lost its identity through the appearance of Indonesian mining law the existence of article 119 Act number 4 year 2009 disregard the rights citizens that has been guaranteed by constitution.

\section{CONCLUSION}

The conflict of law between Indonesian mining law and Indonesian bankruptcy law cut deep through the principles of law and constitutional rights. This conflict of law must be address by citizen through discussion, debate and legal action. The revision of Indonesian mining law is a must but the revision must be powered by citizen interest. It seems like this conflict of law has been outside of the public discourse radar. It is necessary to spread the effort to clearly address this conflict of law and powered it with citizen strong interest. Moreover legal action in the end could be taken.

\section{REFERENCES}

[1] M. Handi Subhan, Hukum Kepailitan: Prinsip, Noma, dan Praktik di Peradilan. Kencana, 2008.

[2] Catur Irianto, "Penerapan Asas Kelangsungan Usaha Dalam Penyelesaian Perkara Kepailitan dan Penundaan Kewajiban Pembayaran utang (PKPU)," J. Huk. dan Peradil., vol. 4, no. 3, p. 401, 2015.

[3] Satjipto Rahardjo, Ilmu Hukum. Bandung: Alumni, 1986.

[4] Paton, A textbook of Jurisprudence. Oxford: Oxford University Press, 1969.

[5] Mahadi, falsafah Hukum: Suatu Pengantar. Bandung: Alumni, 2003.

[6] Kartini Muljadi, Actio Paulina dan Pokok - Pokok Tentang Pengadilan Niaga. 2001

[7] Catur Irianto, "Penerapan Asas Kelangsungan Usaha Dalam Penyelesaian Perkara Kepailitandan Penundaan Kewajiban Pembayaran Utang," J. Huk. dan Peradil., vol. 4, no. 3, p. 406, 2015.

[8] George Sabine, A History of Political Theory. London: George G. Harrap \& Co. Ltd., 1995.

[9] Philipus M. Hadjon, Perlindungan Hukum Bagi Rakyat di Indonesia. Surabaya: Bina Ilmu, 1987.

[10] Ni'matul Huda, Negara Hukum Demokrasi dan Judicial Review. Yogyakarta: UIIPress, 2005. 